\title{
出血性急性實血の創傷治癒に及ほす影響
}

\author{
寺本光廣
}

\section{The effect of hemorrhagic acute anemia on wound healing}

\author{
Mitsuhiro Teramoto
}

\section{緒}

\section{言}

手術法, 麻酔学, 術後管理などのめざましい発達に伴 い, 全身状態不良の患者に対しても，必要に応してて積極 的な外科的療法が適応されてきている。このような患者 は当然生体の抵抗性が減弱し, 手術創の治癒過程は正常 人と異なった過程をたどるものと考えられる。

創傷治癒については, 年㱓差, 性別, 低蛋白血症, 負 血, ビタミン C欠乏症, 糖尿病, 局所循環障害および感 染などが影響するといわれている゙が，これら生体の機 能低下と, 創傷の治撚との関連性については, 過去必ず しも明らかにされていない

創傷の治癒を障害する原因の1つと考えられている貧 血, 特に手術中の出血が，手術創の治嘴過程に影響を及 ぼすか，否かは臨床的に興味のある問題である。創傷治 癒に及ぼす出血性貧血の影響については, 多くの報告が なされているにもかかわらず，出血と手術創との関係は いまだ定説がなく，出血性負血による創傷の治痛遅延を 肯定する説 ${ }^{2,3)}$ と，㓣傷の治㿇遅延を否定する説 ${ }^{4212)}$ と の相反する報告がなされており, 臨床的にも実験的にも その病態に関しては不明の点が多い.

著者は最近の臨床に沶いて, 手術患者の輸血例と輸夜 例の間に創傷治瘉の違いを感じ，この問題の究明の手掛 クとして，まず，出血性貧血の創傷治癒に及ぼす影響を 明らかにすることを考え，脱血による急性貧血家鬼を作 製し, 組織学的および細胞動態学的解析からこの解明を 試みた。

\section{実 験 動 物}

3 週龄の雄性白色家鬼を $2 \sim 3$ 週間飼育して, 順調な 生育を認めた $900 〜 1,100 \mathrm{~g}$ の家鬼247羽を使用した。

愛知学院大学曾学部第 1 口腔外科学教室（主任：深 谷昌彦教授)

The First Department of Oro-Maxillo-Facial Surgery, School of Dentistry, Aichi-GakuinUniversity (Chief: Prof. Masahiko Fukaya)

受付日：昭和55年 4 月 20 日

\section{実 験 方 法}

対照群：非脱血家鬼を用いた。

貧血群：全身的影響の少ない脱血法として, 著者らの 開発した耳静脈維切開法 ${ }^{13}$ により，おのおの $25 \mathrm{ml} / \mathrm{kg}$ body weight の脱血を行い, 急性貧血家兔を作製して, 脱血による急性負血群（以下負血群と略す）に供した.

\section{実験 I}

急性出血の全身的影響を知るため，1）体重変化，2） In液成分の変化，3）各種蔵器の 組織学的変化の 3 項目 について検索を行った。

1) 体重測定

対照群, 貧血群おのおの 5 羽について逐日的に測定を 行った.

2）血液成分の測定

家鬼 5 羽を供し，血液成分の正常値を求め，脱血を行 ったのち逐日的に耳静脈より採血を行い, 赤血球数, 血 色素量, ヘマトクリット值, 血漿蛋白値を測定し, 血液 成分の变化を観察した。测定方法は表 1 に示した。

3) 各種臓器の組織学的検索

対照群: 非脱血家兔 3 羽を供し, 屠殺後たたちに肝 臓, 腎臓, 脾蔵, 胸骨, 大腿骨および下顎骨を摘出し, ヘマトキシリン・エオジン染色および PAS 染色を施 し，組織学的検索を行った.

負血群：9羽の家鬼を供し, 脱血後 $2 ， 4 ， 8$ 日毎に 各 3 羽の家兔を屠殺し，同様の処置を施した。

\section{実験 II}

脱血による急性負血が，創傷の治癒経過に及ぼす影響

表 1 測定項目扣よび測定方法
赤血球数：自動血球計算機
(Erma, ACM-500型)
血色素量 : Cyanmethemoglobin 法 $\mathrm{Hb}$ メーター (Erma, 303 型)
ヘマトクリット值: 毛細管法
$(11,000 \mathrm{rpm} \times 5 \mathrm{~min})$
血漿蛋白値：血漿蛋白計（Erma A-405 A 型） 


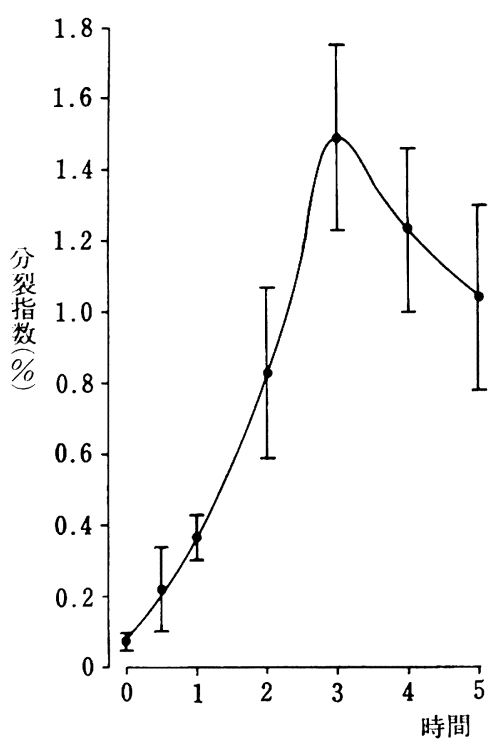

図 1 正常皮㞕に拈ける経時的分裂指数（コルヒチ ข $2 \mathrm{mg} / \mathrm{kg}$ 投与)

について，1）㓣面積の逐日的変化，2）組織学的変化,

3）分裂指数の变化の検索を行った。

創の作製：Paul ら ${ }^{14}$ の方法により外科的開放創（以 下創と略す) を作製した。ソムノペンチル $(0.4 \mathrm{ml} / \mathrm{kg})$ の耳静脈内麻酔下で, 家鬼背部を剔毛し, 消毒後頭尾方 向に 3 分割し，おのおのの中央部に $10 \mathrm{~mm}$ の円形のス タンプにて印をつけ，鋭利なハサミにて印に沿って皮首 を切除し，結合組織を十分に除去して背部笳膜を露出せ しめて創とした。

1）創面積の逐日的測定

対照群 5 羽, 負血群 5 羽の計10羽を用い, 家鬼右側背 部皮简に 3 個所の創を作製し，なんら治療的処置を加兄 なかった，創面の㗞は上皮辺縁を不明膫にし，計測が 不正確になるので, 測定にあたって軽く除去し得る痂皮 はできるだけ除去した後 ${ }^{15 \sim 17)}$, 肉腿的に治癒とみなさ れるまで創の長径,および短径を逐日的にノギスにて計 測して, 長径 $\times$ 短径を㓣面積18)として求めた。求められ た創面積は創作製直後の㓣面積を基準として比率を求 め, 縮小率として表現した。

2) 組織学的検索

治瘾過程を病理組織学的に検索するため, 創の作筡後 1 ～10日の毎日, 対照群, 貧血群各 6 羽, 計 120 羽につ いて試料を採取し，通法に従い組織標本を作製し，一 マトキシリン・エオシンン染色を施し, 組織学的観察を行 い,ささに㭘索結果を数量的にあらわすために, 再生上 皮による㓱面の疮合が完了しているか否かを検定し, 各 洔期に打ける上皮癒合完了率（痹合例数／実験例数）を 求めた.

\section{3）分裂指数の計測}

予供実験：900 1,100 g の正常家鬼 5 羽にコルヒチン $2 \mathrm{mg} / \mathrm{kg}$ を耳静脈より投与し, 経時的に蓄積分裂細胞 数の变化を検索した，その結果 3 時間で蓄皘分裂細胞数 は最大に達し, その正常域の值は $1.5 \pm 0.2 \%$ (分裂指 数)であった（図1）ので，分裂指数の計測にあたって コルヒチン $2 \mathrm{mg} / \mathrm{kg}$ を屠殺 3 時間前に投与することに した。

本実験：創作製後 $12 ， 24$ 時間， $2 ， 3 ， 4 ， 5 ， 6$, 8,10 日ごとに対照群, 䝯血群各 5 羽, 計 90 羽を実験に 供し, 屠殺 3 時間前にコルヒチン $2 \mathrm{mg} / \mathrm{kg}$ を耳静脈内 投与, 試料は採取後ただちに $10 \%$ 中性ホルマリンにて固 定ののち, 通法に従い $4 \mu$ のパラフィン切片を作製し, へマトキシリン・エオシン染色を施した，対照群, 負血 群ともに創辺縁もしくは再生上皮先端より正常部位へ向 かって $1 \mathrm{~mm}$ 間隔で $5 \mathrm{~mm}$ までの範囲を領域 $\mathrm{I} \sim \mathrm{V}$ と し，その沶の打のについて基底細胞数㧍よびその中の分 裂細胞数を計測し、コルヒチン投与による分裂指数（分 裂細胞数／基底細胞数）を算出した。

\section{実 験 結 果}

\section{実験 I}

1）体重の逐日的変化

対照群および貧血群の逐日的体重变化を図 2 に示し た．対照群は規則正しい体重増加を示した。一方，貿血 群では脱血後一時的に体重減少をきたし, 数日は増加を みなかった７日目頃より規則正しい体重增加をみる が，術後 4 週間を経過しても対照群には及ばなかった。 なお, 対照群, 貧血群とも, 創作製による体重への影響 はなかった。

2）血液成分の逐日的変化

血液成分の逐日的变化は脱血前の值（正常値）を基準 とし，その比率で表した（図了）.

赤血球数：脱血12時間後には正常值の $68.1 \%$ と急激に 減少し， 24 時間後に $66.2 \%$ と最低值を記録した後, 徐々 に回復し，2 週間後には $98.6 \%$ とほぼ正常值にまで回復 した.

血色素量：脱血12時間後に正常値の $69.6 \%$ と最低値を 記録したあと, 徐々に回復し, 2 週間後には $100 \%$ 回復 した.

ヘマトクリット値：脱血12時間後に正常値の $68.6 \%$ と 最低値を記録したのち，徐々に上昇して 2 週間後には 99.7\%とほぼ正常值にまで回復した。

血箔蛋白值：脱血12時間後に正常值の $80.9 \%$ と最低値 を記録したが, 赤血球数, 血色素量, へマトクリット值 と比較して影響は少なく, 10日後には正常値にまで回復 した.

3）各種䜟器に与える影響 


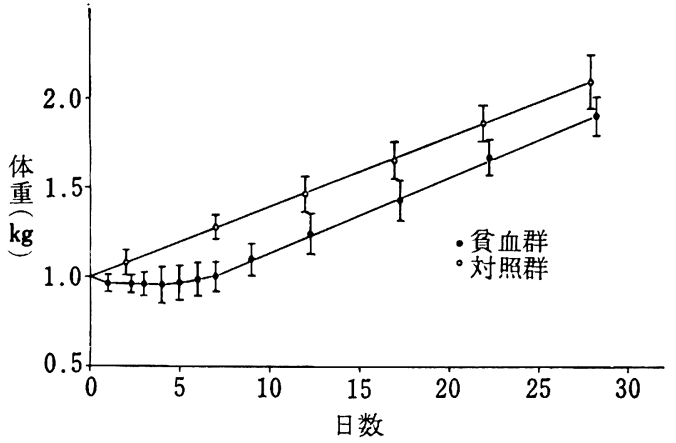

図 2 体重の逐日的变化

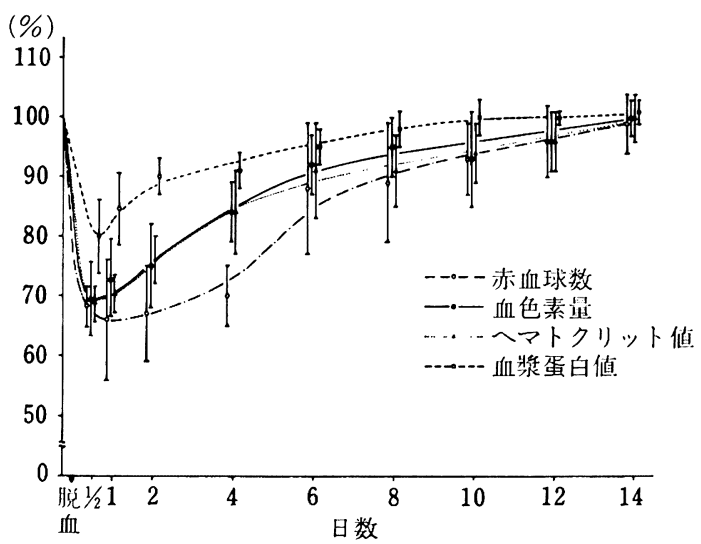

図 3 血液成分の逐日的变化

肝臓, 脾臓, 胸骨, 大腿骨, 下顎骨は対照群の所見と 脱血後 $2 ， 4 ， 8$ 日の組織学的所見との間に差を認めな かったが，脱血群の $2 ， 4 ， 8$ 日の腎蔵の組織学的所見 では，糸球体のごく軽度な萎縮をらかがわせた。

\section{実験 II}

1）創面積の逐日的変化

創作製後の対照群, 負血群の逐日的な創面積比は図 4 のごとくである．対照群では創作製後24時間で68\%にま で縮小したのちも創面積は急速に縮小し，10日頃より縮 小はゆるやかになったが，10～15日で肉眼的に創は閉鎖 した。一方，貧血群では24時間後で73\%に縮小したの ち，4日まではわずかな縮小を示したたけであった，4 日より10日まではほぼ直線的に創面積は縮小し，その後 収縮はゆるやかになり，肉眼的には12〜21日で創は閉鎖 した.

平均治痊日数は対照群では12.8日, 負血群では 16.3 日 であり，貧血群は対照群よりも3.5日の延長を認めた。

2) 組織学的所見

(1) 24 洔間所見

a) 対照群

創中央部では，血餅直下にきわめて高度に密集した炎

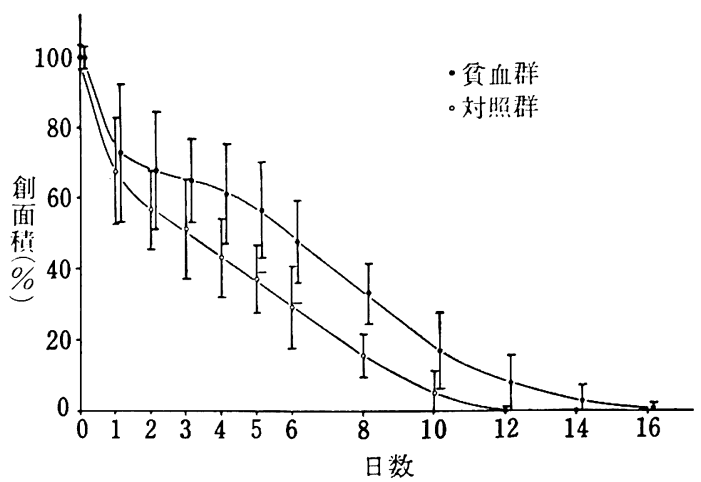

図 4 創面稳の逐日的変化

症性細胞浸潤が筋肉組織にまで認められる。創辺縁部上 皮細胞の核は濃縮を示し, 基底細胞層, 棘細胞層, 顆粒 層は不明瞭で, 結合組織は中等度から高度の炎症性細胞 浸潤, 出血, 血管の拡張, 充血などが認められる（写真 1).

b ) 貧血群

創中央部では，血餅直下に高度の炎症性細胞浸潤を認 め, 対照群とほぼ同様所見を呈している，創辺縁部上皮 細胞は核濃縮し, 結合組織には高度の炎症性細胞浸潤が みられる(写真 2 ).

(2) 2，3 日所見

a ) 対照群

創中央部では, 痂皮直下に極めて密集した炎症性細胞 が認められる。創辺縁部では上皮細胞が増殖し, 核濃縮 を認めない. 上皮は $2 \sim 3$ 層からなり, 基底細胞層, 棘 細胞層はみられるが, 顆粒層, 角質層は認めず, 結合組 織は24時間所見と同様に, 血管の拡張, 充血, 出血を認 めるが，炎症性細胞浸潤は24時間所見ほど著明でない (写真 3 ).

\section{b ) 負血群}

創中央部では, 対照群と同様に痂皮直下にきわめて密 集した炎症性細胞浸潤を認める。創辺縁部では，上皮細 胞は核濃縮を示さないが，上皮細胞の増殖は対照群より 少ない. 上皮細胞は $2 \sim 3$ 層よりなり, 基底細胞層, 棘 細胞層は認められるが，顆粒層，角質層はみられない。 結合組織は対照群と同程度の血管の拡張, 充血, 出血, 炎症性細胞浸潤などが認められる(写真 4 ).

(3) $4 ， 5$ 日所見

a) 対照群

創中央部では，痂皮下には基底細胞，棘細胞からなる $2 \sim 3$ 層の上皮細胞の增殖が認められるが，顆粒尿，角 質層は認められない. 結合組織の炎症性細胞浸潤は, 2，3 日所見と比較してかなり軽度である. 創辺縁部で は, 泇皮下に $3 \sim 10$ 層の肥厚した上皮細胞の増殖が認め られ，基底細胞層，棘細胞層，顆粒層，角質層が規則 


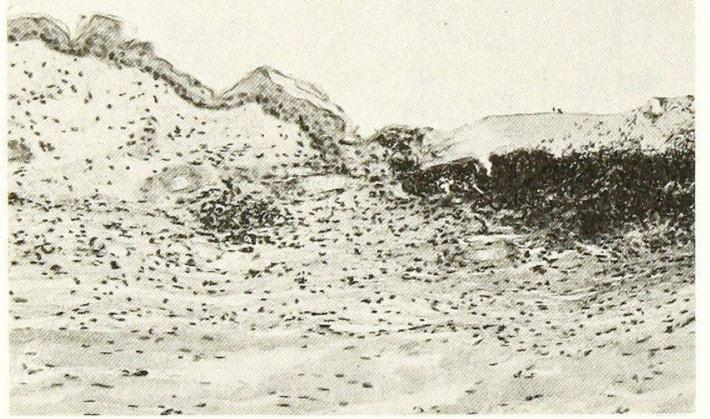

写真 1 対照群 24 時間所見 $(\mathrm{H}-\mathrm{E}$ 染色, $\times 180)$

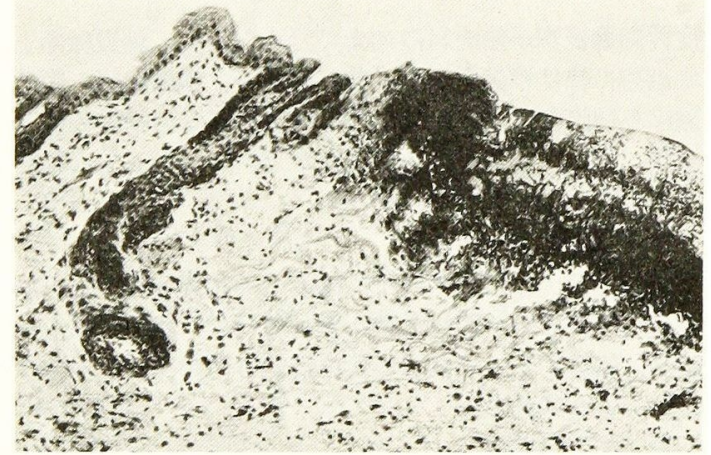

写真 2 賓血群 24 時間所見 $(H-E$ 染色， $\times 180)$

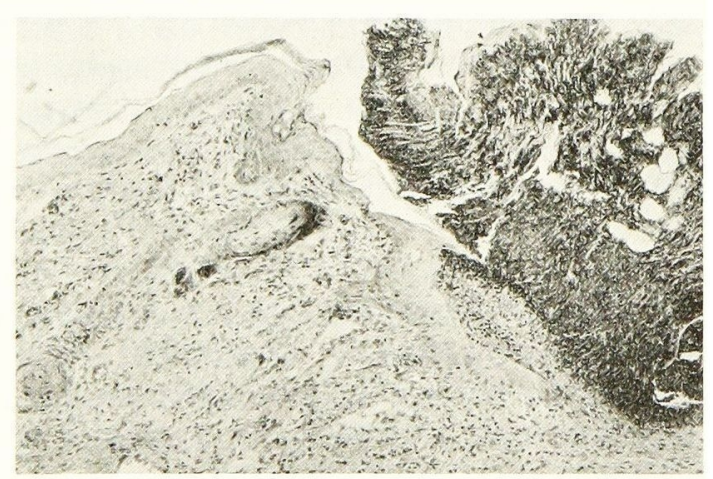

写真 3 対照群 2 日後所見 (H-E 染色, $\times 180$ )

正しく配列している，結合組織は軽度の血管の拡張，充 血，出血，炎症性細胞浸潤などがみられるが，線維芽細 胞は増殖し，線維の走向もかなり規則正しい膠原線維の 形成が随所に認められる(写真 5 ).

b) 角血群

創中央部では上皮形成はみられず，痂皮下には中等度 の资症性細胞浸潤が珰められる，創辺緑部では，㿂皮下 に 3 8 層の基底細胞層, 棘細胞層, 顆粒層, 角質層よ

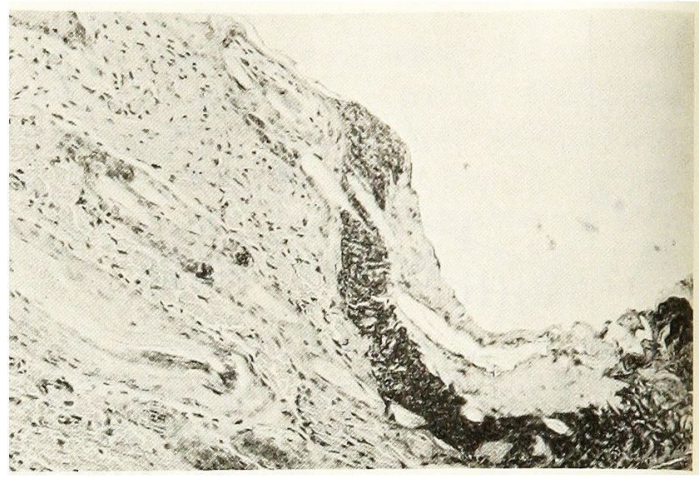

写真 4 貧血群 2 日後所見 $(H-E$ 染色, $\times 180)$

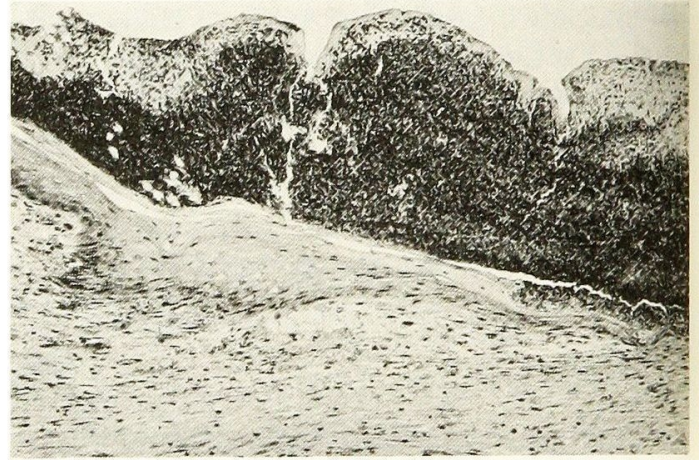

写真 5 刘照群 4 日後所見 $(H-E$ 染色, ×180)

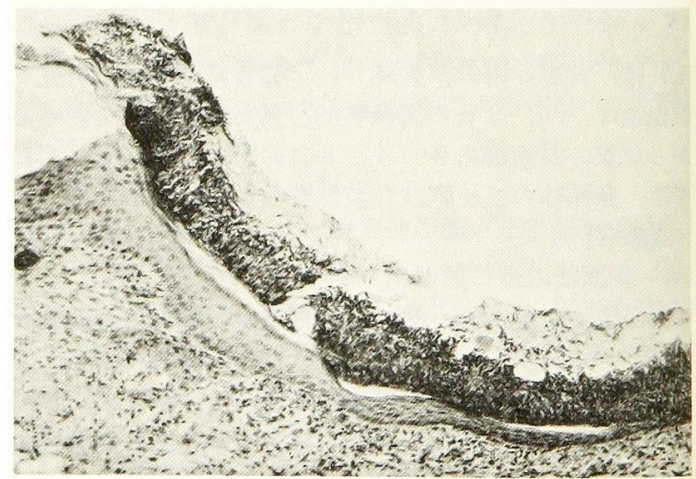

写真 6 貧血群 4 日後所見 $(H-E$ 染色， $\times 180)$

りなる肥厚した上皮が增殖している，上皮の增殖は 2 ， 3 日所見より進行しているが，対照群汪どではない，末 た，結合組織は中等度の血管の拡張，充血，出血および 炎症性細胞浸潤などがみられるが，かなり大量の線維茅 細胞の出現も钼察される(写直 6 ).

(4) $6 ， 7$ 日所見

a) 対照群

創中央部では，痂皮下に 6〜10層の細胞よりなる上皮 


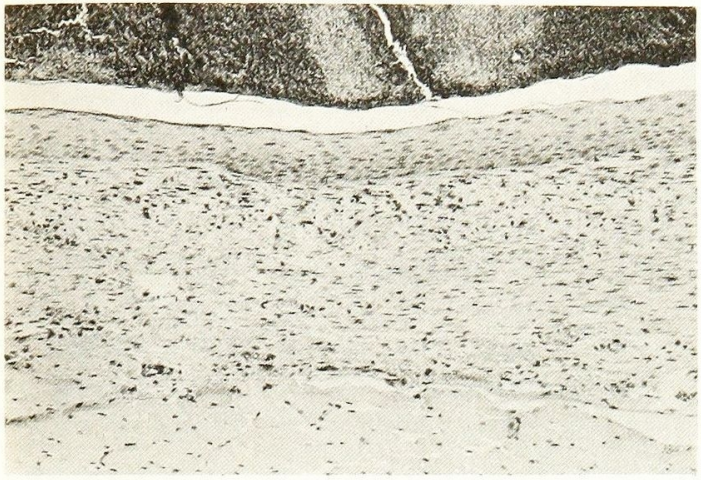

写真 7 対照群 6 日後所見 $(\mathrm{H}-\mathrm{E}$ 染色, × 180$)$

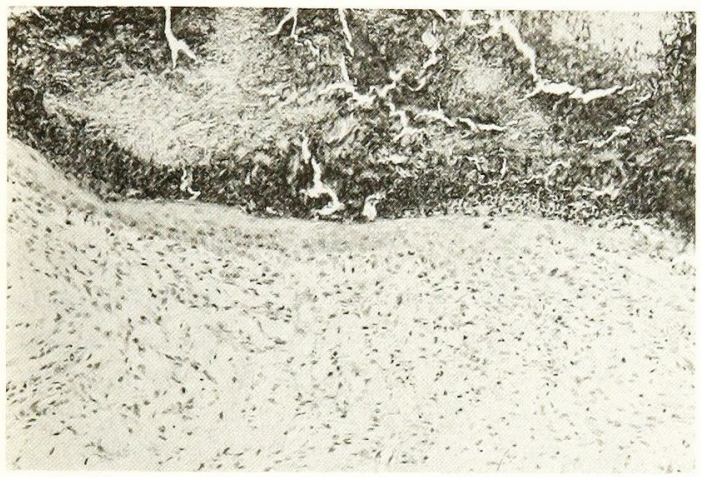

写真 8 貧血群 6 日後所見 $(H-E$ 染色, $\times 180)$

形成がかなり進行し，反対側の上皮と癒合，あるいは癒 合直前の所見をみることができる．瘾合例では上皮に基 底細胞層，來細胞層，顆粒層，角質層が規則正しく配列 している像が観察される，癒合直前例で法基底細胞層， 棘細胞層は認められるが，顆粒層，角質層はみられな い. 結合組織は 4,5 日所見と比較して, 炎症性細胞浸 潤がかなり減少し，線維芽細胞之膠原線維形成が認めら れる (写真 7). 創边縁部では 6〜10 層の 細胞からなる 上皮は基底細胞層, 棘細胞層, 顆粒層, 角質層に規則正 しく配列している，結合組織では新生血管が多く，4， 5 日所見に比較して線維形成もかなり進行し，炎症性細 胞浸潤は減少している。

b）贫血群

創中央部の上皮形成は対照群にど著明ではない上皮 細胞は3〜6 層からなり, 基底細胞層, 濑細胞層は認め られるが，顆粒細胞層，角質層はみられない，痂皮下の 結合組織では，资症性細胞浸潤は軽度で，多数の線維芽 細胞がみられ，少量の膠原線維形成子認められる（写真 8). 創辺縁部では, 瘀皮直下に $6 \sim 10$ 層の上皮細胞が 增值し，基底細胞層，棘細胞層，顆粒㬝，角質層が規則 正しく配列している。結合組織は新生血管，幼弱線維形 成などが認められる。

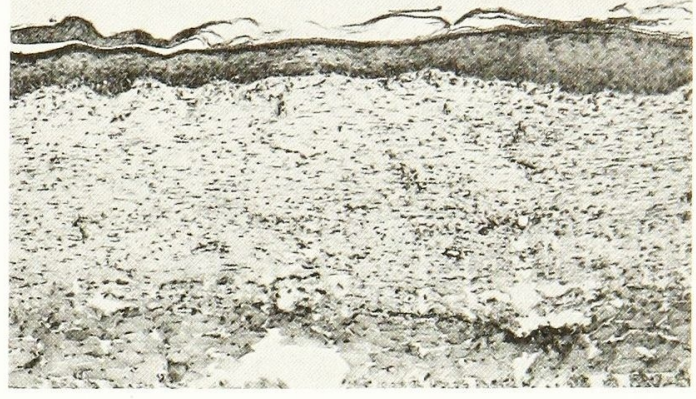

写真 9 対照群 8 日後所見 (H-E 染色, $\times 180)$

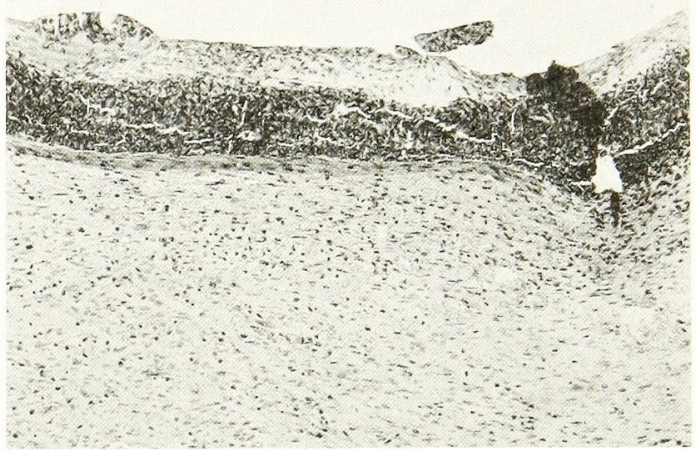

写真 10 貧血群 8 日後所見 $(H-E$ 染色, $\times 180)$

\section{(5) $8 ， 9$ 日所見}

a) 対照群

創中央部の泇皮下では上皮の瘉合が完了し，基底細胞 層，棘細胞層，顆粒層，角質層が規則正しく配列してい る. 結合組織は $6 ， 7$ 日所見よりも新生血管が豊富で, 線維芽細胞扣よび膠原線維も多く、これらの膠原線維は 上皮と平行に配列している(写真 9 ). 創辺縁部む，創 中央部とほとんど同様所見がみられる。

b) 負血群

創中央部では，痂皮下を這うように增殖した数層の細 胞よりなる上皮は，癒合が完了しているか，あるいは癒 合直前であり，結合組織沉は豊富な新生血管と線維芽細 胞扣よび膠原線維が認められるが, 膠原線維の配列は対 照群に比べ不規則である (写真10). 創辺縁部は, 対照 群のように 4 8 層の細胞からなる上皮が認められ，基 底細胞層，棘細胞層，顆粒層，角質層が規則正しく配列 しているのが観察される．結合組織は新生血管に富み, 線維芽細胞捛よび膠原線維は上皮と平行に配列してい る.

(6) 10 日所見

a) 対照群

創は完全に上皮で覆われ，痂皮は脱落し，創中央部の 


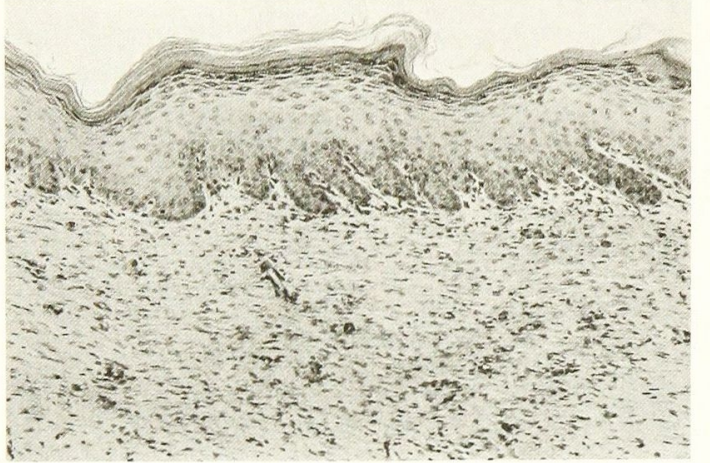

写真 11 対炤群10日後所見 $(H-E$ 染色, $\times 180)$
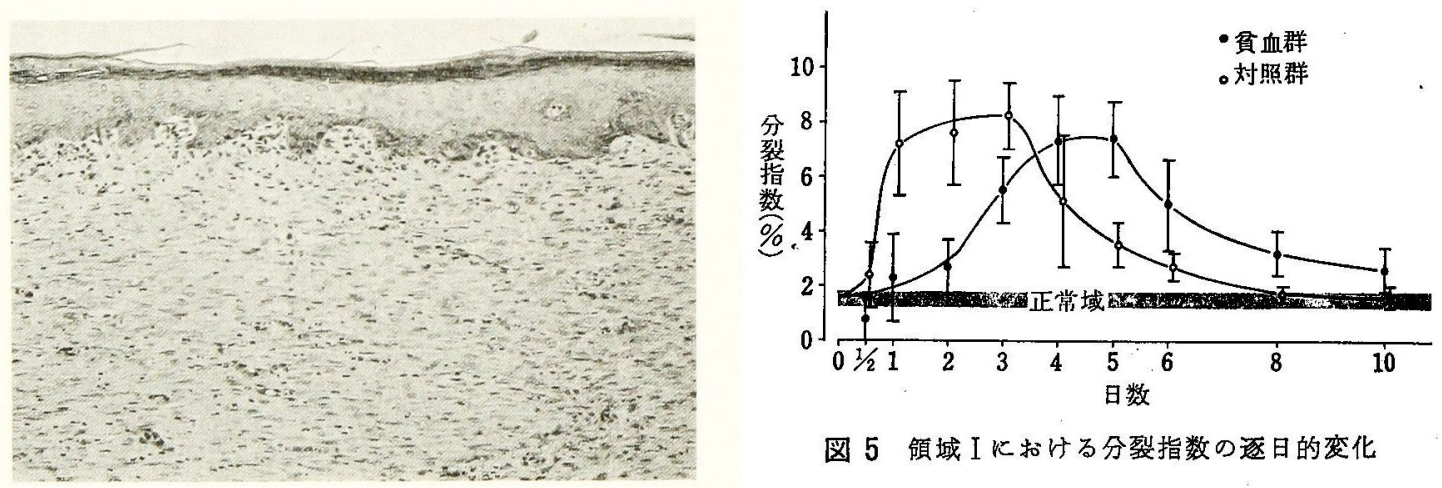

図 5 頂城Iに打ける分裂指数の逐日的变化

\begin{tabular}{c|c|c}
\hline 日 数 & 対炤群 & 貧血群 \\
\hline 4 & $0 / 18(0 \%)$ & $0 / 18(0 \%)$ \\
5 & $6 / 18(33.3 \%)$ & $0 / 18(0 \%)$ \\
6 & $10 / 18(55.6 \%)$ & $3 / 18(16.7 \%)$ \\
7 & $15 / 18(83.3 \%)$ & $9 / 18(50.0 \%)$ \\
8 & $18 / 18(100 \%)$ & $12 / 18(66.7 \%)$ \\
9 & $18 / 18(100 \%)$ & $15 / 18(83.3 \%)$ \\
10 & $18 / 18(100 \%)$ & $18 / 18(100 \%)$ \\
\hline
\end{tabular}

写真 12 貧血群10日後所見 (H-E 染色, $\times 180)$

表 3 開放創作製後の分裂指数

\begin{tabular}{|c|c|c|c|c|c|c|c|c|c|c|}
\hline & & 12時間 & 24 時間 & 2 日 & 3 日 & 4 日 & 5 日 & 6 日 & 8 日 & 10日 \\
\hline I & $\begin{array}{l}\text { 贫血群 } \\
\text { 対炤群 }\end{array}$ & $\begin{array}{l}0.79 \pm 0.84 \\
2.42 \pm 1.24\end{array}$ & $\begin{array}{l}2.27 \pm 1.69 \\
7.26 \pm 1.78 \\
\end{array}$ & $\left|\begin{array}{l}2.67 \pm 1.03 \\
7.84 \pm 1.63\end{array}\right|$ & $\left\{\begin{array}{l}5.49 \pm 1.19 \\
8.17 \pm 1.24\end{array} \mid\right.$ & $\left|\begin{array}{l}7.33 \pm 1.56 \\
5.57 \pm 1.64\end{array}\right|$ & $\left|\begin{array}{l}7.39 \pm 1.27 \\
3.46 \pm 1.09\end{array}\right|$ & $\left|\begin{array}{l}4.95 \pm 1.60 \\
2.69 \pm 0.51\end{array}\right|$ & $\left|\begin{array}{l}3.17 \pm 0.81 \\
1.73 \pm 0.34\end{array}\right|$ & $1.62 \pm 0.45$ \\
\hline II & $\begin{array}{l}\text { 貧血群 } \\
\text { 対炤群 }\end{array}$ & $\begin{array}{l}0.80 \pm 0.45 \\
1.71 \pm 1.04\end{array}$ & $\begin{array}{l}1.87 \pm 0.79 \\
3.77 \pm 1.81\end{array}$ & $\begin{array}{l}0.91 \pm 0.62 \\
2.88 \pm 1.39\end{array}$ & $\begin{array}{l}3.35 \pm 1.65 \\
4.96 \pm 1.48\end{array}$ & $\left|\begin{array}{l}2.71 \pm 1.44 \\
3.23 \pm 1.60\end{array}\right|$ & $\mid \begin{array}{l}2.36 \pm 0.70 \\
2.10 \pm 0.53\end{array}$ & $\begin{array}{l}3.51 \pm 1.47 \\
1.84 \pm 0.50\end{array}$ & $\left|\begin{array}{l}1.63 \pm 0.47 \\
1.48 \pm 0.58\end{array}\right|$ & $\begin{array}{l}1.28 \pm 0.57 \\
1.68 \pm 0.72\end{array}$ \\
\hline III & $\begin{array}{l}\text { 負血群 } \\
\text { 対炤群 }\end{array}$ & $\begin{array}{l}1.40 \pm 1.18 \\
1.45 \pm 1.46\end{array}$ & $\begin{array}{l}1.73 \pm 1.25 \\
2.33 \pm 1.79 \\
\end{array}$ & $\mid \begin{array}{l}0.92 \pm \\
1.94 \pm\end{array}$ & $\begin{array}{l}1.67 \pm 0.70 \\
1.93 \pm 0.84\end{array}$ & $\begin{array}{l}2.26 \pm 1.19 \\
1.74 \pm 0.97\end{array} \mid$ & $\left|\begin{array}{l}1.75 \pm 0.79 \\
1.47 \pm 0.57\end{array}\right|$ & $\begin{array}{l}1.31 \pm 0.63 \\
1.33 \pm 0.41\end{array}$ & $\left|\begin{array}{l}1.15 \pm 0.38 \\
1.10 \pm 0.37\end{array}\right|$ & $\begin{array}{l}0.97 \pm 0.65 \\
1.73 \pm 0.35\end{array}$ \\
\hline IV & $\begin{array}{l}\text { 貧血群 } \\
\text { 対炤群 }\end{array}$ & $\begin{array}{l}1.19 \pm 0.81 \\
1.17 \pm 1.10\end{array}$ & $\begin{array}{l}1.27 \pm 1.09 \\
1.88 \pm 1.69\end{array}$ & $\begin{array}{l}1.22 \pm 0.52 \\
1.71 \pm 2.02\end{array}$ & $\begin{array}{l}1.27 \pm 0.76 \\
1.40 \pm 0.67\end{array}$ & $\left|\begin{array}{l}1.89 \pm 1.13 \\
1.72 \pm 1.02\end{array}\right|$ & $\left|\begin{array}{l}1.90 \pm 0.46 \\
1.53 \pm 0.38\end{array}\right|$ & $\mid \begin{array}{l}1.07 \pm 0.66 \\
1.41 \pm 0.46\end{array}$ & $\left|\begin{array}{l}1.18 \pm 0.48 \\
0.96 \pm 0.38\end{array}\right|$ & $\begin{array}{l}0.96 \pm 0.43 \\
1.51 \pm 0.58\end{array}$ \\
\hline V & $\begin{array}{l}\text { 貧血群 } \\
\text { 対照群 }\end{array}$ & $\begin{array}{l}1.02 \pm 1.13 \\
1.39 \pm 0.97\end{array}$ & $\begin{array}{l}1.35 \pm 0.58 \\
1.17 \pm 1.10\end{array}$ & $\left\{\begin{array}{l}1.01 \pm 1.08 \\
2.30 \pm 2.23\end{array} \mid\right.$ & $\begin{array}{l}1.15 \pm 0.60 \\
1.92 \pm 1.18\end{array}$ & $\left|\begin{array}{l}1.56 \pm 0.87 \\
1.06 \pm 0.79\end{array}\right|$ & $\begin{array}{l}1.94 \pm 1.09 \\
1.22 \pm 0.31\end{array} \mid$ & $\left\{\begin{array}{l}0.99 \pm 0.54 \\
1.36 \pm 0.51\end{array}\right.$ & $\left|\begin{array}{l}1.17 \pm 0.45 \\
0.95 \pm 0.33\end{array}\right|$ & $\begin{array}{l}0.90 \pm 0.23 \\
1.74 \pm 0.72\end{array}$ \\
\hline
\end{tabular}

上皮では基底細胞層，棘細胞層，顆粒層，角翼畨が明暸 に認められる。結合組織には新生血管が貫富で，膠原線 維は規則正しく走问しているが，一部には極く軽度の炎 症性細胞浸潤がみられる（写直11）.

b）畕血群

創は完全に上皮で覆われ，その上に湤皮が残存してい
るものと，脱落しているものがある．創中央部の上皮で は，基底細胞層，棘細胞層，顆粒層，角質層がかなり明 膫であり，結合組織の膠原線維は対照群に比べ不規則 で，炎症性細胞浸潤も軽度に認められる(写真12).

(7) 上皮癒合完了率

創作慜後の再生上皮による瑲面痹合を組䄉学的に検索 
した，逐日的な上皮掩合完了率を表 2 に示した。

対照群では，5日後ですでに33.3\%に痰合の完了が認 められ，6日で55.6\%，7日で83.3\%，8日では全例に 再生上皮による癒合完了をみた。一方，貧血群では， 6 日後に初めて $16.7 \%$ 瘣合がみられ，7日で $50.0 \%$, 8 日で66.7\%，9日で83.3\%，10日後には全例に再生上 皮による癒合が認められ，負血群は対熙群よりも2 日程 度の上皮瘉合の逤延を認めた。

3）分峢指数の逐日的变化

創作製後12時間より10日までの分列指数は対照群，貧 血群ともに領域 I に打いて最も著しい分裂指数の増加を 認め，次いで領域IIにおいて分裂指数の增加がみられた が, 領域 III, $N 、 V$ では正常值との差を認めなかった (表了).

領域 Iにおける創作製後の分到指数の逐日的な変化を 図 5 に曲線で示した。対照群では，侴作憋後12時間より 分裂指数は急激な上昇を示し，24時間後には7.3土1.8\% と 3 日後の最高値 $8.2 \pm 1.2 \%$ にほほ近い值にまで上昇し た。 その後は徐々に減少を始め，6日後には $2.7 \pm 0.5 \%$ とわずかな上昇を認めるたけで，8日後には $1.7 \pm 0.3 \%$ とほほ正常値に等しい值を示した。一方，負血群では創 作製後24時間より分裂指数は徐々に上昇を始め，4 日後 に7.3土1.6\%と最高值近くまで上昇し， 5 日後の $7.4 \pm$ $1.3 \%$ ピークとし，その後徐々に減少を始め，10日後 には2.6土0.8\%となり，正常域よりやや高い值にまで低 下した。すなわち, 貧血群は対照群よりも分裂開始時期 に遅延がみられ，対照群を追らがごとく上昇し，2日遅 れて最高値を示したが，その後も対照群に近ついたもの の, 全期間を通じ，2〜3 日程度の遅延を認めた.

\section{総括および考察}

色血の創傷治癒に及ぼす影響に関する研究は, 古くか ら多くの文献に接することができる。臨床面で，1966年 Guiney ら2) は，腹部手術後に創の桨開をきたした症例 の50\%が貧血例であったのに対し，正常治瘉を示した症 例に含まれる預血例は20\%であったと報告，貧血が創傷 の治嘴に関与することを示唆した。一方，Marsh ら $(1954)^{4)}$ は手術㓣の哆開と貧血の関係はないと報告,

Mann ら $(1962)^{5)}$, Alexander ら $(1966)^{6)}$ も同様の見 解を示すなど，2つの相反する報告がみられ，問題が提 起されたままになっている。

動物による実験的研究も種々接するが，脱血の直接 影響に関するものは少ない. Sandblom (1944) ${ }^{3)}$ は家鬼 の頸動脈より，総量 $20 \sim 45 \mathrm{ml}$ の脱血を行ったあとに 作製した創の術後 5 日の抗張力が，正常家鬼に作られた 創の抗張力より低值を示したと報告し, 抗張力から貧血 の治癒に対する影響を指摘している。多くの報告は脱 If 後, 血漿輸血, Dextran 輸液などの影響を考虑したもの

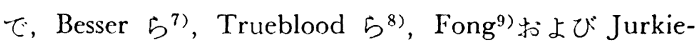

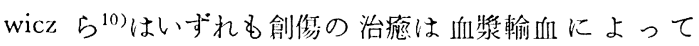
脱血による影愁を受けないと述べ, Sandberg ら Dextran 輸液が同様結果を得ると報告している.しかし， これらの多くの研究はいずれも条件がまちまちであり， この問題を結論づけるような内容を示していない.

創傷治瘉の钼察について 1929年 Howes $5^{19)}, 1930$ 年 Harvey $5^{20)}$ による治嘴速度を客観的に表す方法と して，創賃部の抗張力を用いる方法が報告されて以来， この方法が負血と創㑺に関する研究に多く応用されてい る3,7 9,11). しかし，摘出した試料片より求めた抗張力

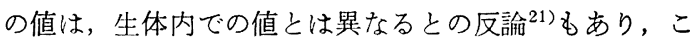
の方法が創倁治痛を検討するに最良の方法とは思えな いまた，㓣の肉腿的所見から創面積を逐日的に测定し て, 創の縮小率から治癒速度を追求し, 治瘉経過を数量 的に解析する試みは, Carrel (1916) ${ }^{22)}$ 以来多く用いら れ，応用による種々の㬰験方式が報告されている23 25). また，組織欠損の修復過程に関する組織学的観察は当然

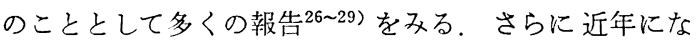
って, コルヒチンを用いた細胞レベルでの研究 ${ }^{30 ~ 34) ~ b ~}$ 行われ, 分裂指数の变動なとからの治㾤過程の追求も行 われている。

㓣傷の治癒過程を観察するには, 数量的計測, 肉眼的 観察, 力学的検索, 組織学的検索, 生化学的検索, オ一 トラジオグラフィーなどの幅広い分野からの検索を行 い, 総合して判断を下すことが必要であり, 負血と創傷 との関係を論ずるには, 動物の設定, 負血の条件の規 定, 治癒過程の検索法など十分に検討されなければなら ない.

著者は, 過去比較的多く用いられている家鬼を実験動 物として選び, 侴面積の逐日的変化の追求, 病理組織学 的検索拉よび組織像からみた逐日的上皮瘉合率の算定, 細胞レベルから分裂指数の後動など多面的な観察を試み た.

また，本実験は急性負血動物の条件を一定にするこ と，創傷に及ぼす影響に負血以外の要素を入れないこと が必要であり，脱血操作による侵襲をできるたけ小さく する必要があると考えた，従来，家兔の脱血方法として は, 心臓穿刺法 ${ }^{9,12)}$, 頸動脈穿刺法 ${ }^{3,35)}$, 大腿動脈穿刺 法"1)が多く用いられている。しかし, 著者ら ${ }^{13)}$ が報告し たよらに,これらの方法は総頸動脈圧に著しい変動を示 し，呼吸抑制などを併発して，大量の脱血に耐えないな ど，脱血操作による全身的影響が大きいことがうかがわ れた。 著者らの開発した耳静脈縱切開法は, $25 \mathrm{ml} / \mathrm{kg}$ の脱血で操作中臨床的著变を示さず, 総頸動脈圧の変化 も比較的緩やかな影響を受けるにすきず，50分程度の経 過で回復しており，本夹験に適する脱血法と考え，この 方法を採用した。

まず，成長期家鬼を用い，耳静脈維切開法による 25 
$\mathrm{m} l / \mathrm{kg}$ 脱血の全身的影響を検索した，体重の逐日的変化 では, 対照群が規則正しい体重増加を示すのに対して, 貧血群は一時的に体重減少がみられたのち横ばいを続 け，7 日頃から規則正しい増加を続ける。体重増加曲線 は対照群をやや追っているが，脱血後 4 週間を経てもな 拉対照群の体重には及ばない，多量の急激な脱血は成長 期の家鬼に長期間にわたって影響するものと考えられ る。渡辺 ${ }^{36}$ は創形成の体重に及ぼす影響について, ラッ トの腹部に長さ $5 \mathrm{~cm}$ の全層に達する切創を加えたとこ ろ, 術後に軽度の体重減少をみたが, 2 病日には早くも 增加傾向があり, 3 病日には術前値に回復し, 以後順調 に增加したと述べている，著者の今回の実験では, 動物 の大きさに比して侵襲が小さいためか, 対照群, 貧血群 ともに創作製による体重への影響はなかったと思われ る.

血液所見にみられる脱血の影響は，血漿蛋白値に最も 少なく，12時間後に19.1\%の減少をみたにとどまり，10 日後には回復をしている. 血色素量, へマトクリット值 は12時間後に約30\%の減少をみたのち，2 週間でほぼ回 復し, 最も大きく影響した赤血球数は12時間で, 血色素 量, ヘマトクリット值と同様の減少であったが, 24時間 で約34\%の最大減少值を示している。血夜所見は 7 日頃 まで急激な回復を示し, 以後緩やかに回復し,すべての 回復はほぼ 2 週間であった。脱血の影響が血漿蛋白值に 最も少なく，赤血球数に最も大きかったが，これは血漿 蛋白が体蛋白からの移行により容易に代償されるのに対 し, 赤血球数は Erythropoietin が未分化な幹細胞に作 用して増生されるまでには，かなり長時間を要するため ではないかと推測される。また, 脱血後に一時的に減少 し, 横ばいを続けた体重は, 血漿蛋白值が正常値に近づ く7 日頃より規則正しい增加を示したが，血漿蛋白值の 減少が成長期の家鬼の体重增加にも悪影響を及ぼすので はないかと思われる。

次に脱血の創傷治痛に及ぼす影響を検索するため，ま ず, 径 $10 \mathrm{~mm}$ の可及的に一定にした創を, 作製後の肉 眼的な逐日的変化を創面積比で比較した．対照群では創 作製後創面積は停滞することなく急速に縮小したのに対 し, 貧血群では術後 5 日までは緩徐な縮小を示したたけ であり，その後対照群とほとんと平行な治痹曲線をたど り, 肉眼的治癒の平均日数は対照群 12.8 日であるのに対 し, 負血群は16.3日と延長している。渡邊 ${ }^{15)}$ は作製され た創面積平均値がほぼ等しい場合, 平均治瘜が遅い群は 早い群に比べて, 治瘾が不良であると考えてよいと述べ ている。この考方方からすれば肉眼所見のみで，すでに 急性負血が創傷治癒に悪影響を及ぼしたるのと考兄るこ とができる。また，創面積の縮小率からみた場合，脱血 による創傷治疹への影響は, 創作製後の初期, 特に 5 日 頃までの問に著しいと考えられる。すなわち，能势28)ら が述ぺている創傷治癒の初期数日間の停滞期が, 負血群
では対照群に比べて長く，この原因としては，上皮形成 の開始時期の遅延が原因と考えられる.

そこで著者は，この推測を明らかにするため，逐日的 な組織学的観察を行った。対照群では創作製後 2 日で上 皮の形成がかなり進行し，6，7 日で膠原線維の形成か 中等度にみられ，8，9 日ではその走向が規則正しくな っている。一方, 貧血群では創作製後 2 日では上皮形成 は認められるもののごく少量であり，6，7 日では膠原 線維はごく少なく，8，9 日になっても走向は不規則で あり, 組織学的にも対照群に比較して $2 \sim 3$ 日程度の遅 延が認められた。ささらに，著者は組織学的な検索結果を 数量的に表すために，逐日的に再生上皮による癒合完了 率 (癒合例数/実験例数) を求めた。 その結果, 対照群 が創作製 5 日後に $33.3 \% ， 8$ 日で全例に再生上皮による 癒合を認めたのに対し, 負血群は 5 日では 1 例の癒合例 もなく，8日で66.7\%，10日で全例の上皮性癒合がみら れ, 貧血群は対照群よりも 2 日程度の創傷治瘾遅延を示 し, 上皮形成の遲延が創面積の縮小遅延の原因であるこ とを認めた。

次著者はコルヒチン 3 時間蓄積による分裂指数を比 較検討した結果, 筫血群の再生上皮による癒合完了時期 の遅延と, 領域 I の分裂指数の変動の遅延との間に相関 関係を認めた，すなわち，対照群では創作製後12時間よ り分裂指数は急增加を示し，24時間後にはほほ最高值に まで增加し，3 日後より減少を始め，再生上皮による瘺 合が完了寸る時期に一致して，分裂指数は術前值とほぼ 等しい值にまで低下していた。一方，負血群では24時間 より分裂指数は徐々に增加を始め, 5 日後に最高值を示 し，その後徐々に減少し，10日後になりほぼ術前値にま で低下したが，逐日的な分裂指数の検索結果は, 組織学 的所見と同様に, 貧血群は対照群よりも $2 \sim 3$ 日の荤延 を認めた。

以上の実験成績から $25 \mathrm{ml} / \mathrm{kg}$ 脱血による急性筫血が 成長期の家鬼背部皮廉の創傷治瘾に及ぼす影響は $2 \sim 3$

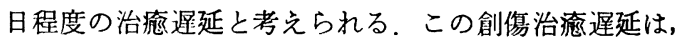
創作製後の初期変化において, 組織の創傷修復帰転に当 然增大してくる細胞分裂が, 貧血群では対照群ほど著明 ではなく，しかも2〜3日の遅延を示した。 その結果と して, 組織学的には貧血群に打ける上皮形成の $2 \sim 3$ 日 の遅延として観察され, 肉眼的には創面積縮小率の 2 3 日の逮延をきたしたものと考えられる。

このような㓣伤治痹遅延の原因として, Rhoads ら $\left.(1942)^{37}\right)$ は血清アルブミンが創傷治癒過程に大きな影響 を及ぼすとし，術前より低蛋白血症を示するのに手術侵 襲を加えると，血清アルブミンは一層減少し，創傷治瘺 逯延をきたすと述べ，渡辺 $(1967)^{36)}$ はラットで 8 種類 の必須フミノ酸の，1つずつ欠除した食慨で飼育したと ころ, Valine, Methionine, Lysine, Phenylalanine をそ れぞれ欠除した食餉群の皮凨切開部の抗張力は, 対照群 
より15〜30\%低かったと報告し，Daly (1972) ${ }^{38)}$ はラッ トを用いて術前 4 週間蛋白食を与えずに低蛋白血症を作 製し，腸管吻合を行い耐生力を测定した結果，対照群よ り $25 \%$ 低かったと報告している，以上のように手術侵襲 により血漿蛋白値は一時的に減少し，これが創傷治捇過 程に少なから灣を及ぼしていることが推定される。 著者の実験でも， $25 \mathrm{ml} / \mathrm{kg}$ 脱血により脱血前值よりる 約 $20 \%$ 血漿蛋白值の減少を認めたが，手血の影響に関す る実験には考虛されなければならない要素が多く，本拜 験においても，2３日の創傷治嘴遅延が脱血による低 血漿蛋白だけに由来するとは考兄られない.

Schires ら (1961) ${ }^{39}$ は $\mathrm{Cr}^{51}, \mathrm{I}^{131}, \mathrm{~S}^{35}$ を用いて赤血 球数, 循環血液量, 細胞外液を測定し, 外科侵襲時には 細胞外液の喪失がかなり多いことを発表した。 Fountain ら (1966) ${ }^{40)}$ は外科的手術操作を模する意味において， ラットを開腹し腸管をガーゼで軽く摩擦したところ，そ の部分の組織特に漿膜下組織に非常に大量の血漿成分が 眝留すると報告し，Adamsons ら (1967) ${ }^{41)}$ は皮店に切 㓣を作製したところ，創部に $4 \mathrm{~g} / 100 \mathrm{~g}$ tissue の水分眝 留を認めたと述べている。また，Hunt ら (1967) ${ }^{42)}$ は 循環血液量減少により, 創部への酸素供給が極度に減少 すると報告し，創部の酸素王低下は創傷治瘾を遅延させ るとの報告 ${ }^{43,44)}$ もみられる。本実験は開腹術, 開胸術と は違い, third space への水分喪失は軽微と思われる が，開放創であるため Adamsons $5^{41)}$ と同程度以上の 局所の水分貯留および $25 \mathrm{ml} / \mathrm{kg}$ 脱血による循環血液量 の減少は否定できず，Hunt ら 42 44)の述べているよう に, 循環血液量の減少により㓣部の酸素分圧が低下した ために修復性の細胞分裂能が弱まり, 上皮の再生が阻害 され，創傷治瘉の遅延が生じたとも考えられる。

\section{結語}

$25 \mathrm{ml} / \mathrm{kg}$ 脱血による急性瑻血が，900〜 1, 100 g の成 長期家鬼に及ぼす影響を比較検討し次の結果を得た。

1. 貧血群では脱血後一時的に体重減少をきたし，術 後 4 週間を経過してもなお対照群には及ばず，多量の脱 血は成長期の家兔に長期にわたって影響を及ぼす。

2. $25 \mathrm{ml} / \mathrm{kg}$ 脱血による血液成分への影響は約 2 週間 であった。

3. 創面積縮小率を比較した結果, 貧血群は対照群よ り 2 〜 日の創傷治㾏遅延を認めた.

4. 組織学的検索結果より, 負血群は対照群より 2 3 日の創傷治癒遅延を認めた。

5. 逐日的分裂指数測定において, 負血群は対照群よ りも2〜3 日の遅延を認めた.

6. 組織学的検索, 分裂指数の逐日的観察から, 貧血 群と対照群の治癒過程の相違は, その初期において著し かった。
稿を終えるに臨み，ご指送，こ校閲を晹った教空主任 些谷昌彦教授に深謝致します。またこ教示を晹った病 理学教空龟山洋一郎教授およびこ協力志晹った第 1 口腔 外科学教室員各位に謝意を表します。

本諭文の要旨は, 昭和 54 年 4 月, 第 33 回日本口腔科学 会総会拉よび昭和54年10月，第24回日本口腔外科学会総 会において発表した。

\section{引用文 献}

1）毛利喜久男：創㑺治彩の生化学の進歩。臨外 30: 9831975.

2) Guiney, E.J., et al.: Wound dehiscence. Arch Surg 92: 471966.

3) Sandblom, P.: The tensile strength of healing wounds. Systemic factors. Anemia and dehydration. Acta Chir Scandinav 90 (Supp. 89): 711944.

4) Marsh, R.L., et al.: Factors involving wound dehiscence. Study of one thousand cases. JAMA 155: 11971954.

5) Mann, L. S., et al.: Disruption of abdominal wounds. JAMA 180: 991962.

6) Alexander, H.C., Prudder, J.F.: The causes of abdominal wound disruption. Surg Gynec Obstet 122: 12231966.

7) Besser, E.L., Ehrenhaft, J.L.: The relationship of acute anemia to wound healing. Surg 14: 2391943.

8) Trueblood, H.W., et al.: The effect of acute anemia and iron deficiency anemia on wound healing. Arch Surg 99: 1131969.

9) Fong, T.P., et al.. Chronic anemia, wound healing, and red cell 2,3-diphosphoglycerate. Surg 79: 2181976.

10) Jurkiewicz, M.J., Garrett, L.P.. Studies on the influence of anemia on wound healing. AM Surg 30: 231964.

11) Sandberg, N., Zederfeldt, B.: Influence of acute hemorrhage on wound healing in the rabbit. Acta Chir Scandinav 118: 367 1959/ 1960.

12) Heughan, C., et al.: The effect of anemia on wound healing. Ann Surg 179: 1631974.

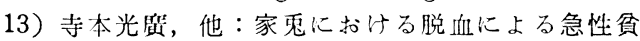

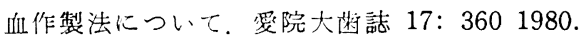

14) Paul, H.E., et al.. Biochemistry of wound healing. I. The thiamine content of healing tissue of skin wounds. Arch Biochem 7: 231 1945.

15）渡邀治生：酸性及ビ「アルカリ」性食慨ノ創伤 治瘾二及ボス影響二阅スル夹駼的研究。日外会 誌 38: 16561938.

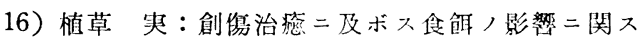


儿実験的研究。日外会誌 44：10301944.

17）大下久代：創匴治瘾に及ほすクロルプロマジン 扣よび低体温の影瑵に関少る破究。東邦医誌 8: 10071961 .

18）牛島康栄，他：創懏治痖過程の情報処理につい て。現代の臨休 9: 521975.

19) Howes, E.L., et al.: The healing of wounds as determined by their tensile strength. JAMA 92: 421929.

20) Harvey, S.C., Howes, E.L.: Effect of high protein diet on the velocity of growth of fibroblasts in the healing wound. Ann Surg 91: 6411930.

21) Hugo, N.E., et al.: Effect of chronic anemia on the tensile strength of healing wounds. Surg 66: 7411969.

22) Carrel, A., Hartmann, A.: Cicatrization of wounds. I. The relation between the size of a wound and the rate of its cicatrization. J Exp Med 24: 4291916.

23) Noüy, P.L.: Cicatrization of wounds. II. Mathematical expression of the curve representing cicatrization. J Exp Med 24: 4511916.

24）奥田毒正：創伤治虑二闺スル研究。日外会誌 32: 11931.

25）大喽敏雄：創伤治崅の数学的表現。科学 8: 5621938.

26) Howes, E.L.: The rate and nature of epithelization in wounds with loss of substance. Surg Gynec Obstet 76: 7381943.

27) 阪本義樹：創伤治㗪過程の組織化学的研究。阪 大随誌 4：643 1959.

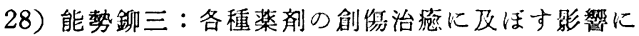
ついて。十全会誌 72: 4241966.

29）井上四郎：表皮細胞の增殖と分化に関与る研 究，特に ${ }^{3} \mathrm{H}$-thymidine Autoradiography によ る再生過程についての検索。日整会誌 43: 581 1969.

30) Gelfant, S.: A study of mitosis in mouse ear epidermis in vitro. I. Cutting of the ear as mitotic stimulant. Exp Cell Res 16: 5271959.

31) Gelfant, S.: Initiation of mitosis in relation to the cell division cycle. Exp Cell Res 26: 395
1962.

32) Blenkinsopp, W.K.: Cell proliferation in the epithelium of the oesophagus, trachea and ureter in mice. J Cell Sci 5: 3931969.

33）山田史郎：凁結による皮度損匴と回復の細胞動 態論的解析。 日口外誌 19:518 1973.

34）田邊 昭：表皮稩胞の增殖と分化に対する放射 線の影䈕——表皮に打ける增殖単位 (EPU) か らの解析一一日口处誌 26：270 1980.

35) 向井浄, 任藤誠治, 富山募六: 実験的急性出 血に対する5\%マルトース加乳酸リンゲル液 (MI-5 L) の効果。薬理と治療 5：990 1977.

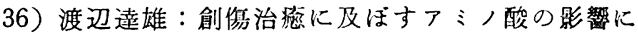
関する研究。日外会誌 68: 3951967.

37) Rhoads, J.E., Fliegelman, M.T., Panzer, L. M.: The mechanism of delayed wound healing in the presence of hypoproteinemia. JAMA 118: 211942.

38) Daly, J.M.: Effects of protein depletion on strength of colonic anastomoses. Surg Gynec Obstet 134: 151972.

39) Schires, T., Williams, J., Brown, F.: Acute change in extracellular fluids associated with major surgical procedures. Ann Surg 154: 8031961.

40) Fountain, S.S., Schloerf, P.R.. The dynamics of posttrumatic intestinal fluid sequestration. Surg Gynec Obstet 123: 12371966.

41) Adamsons, R. J., Musco, F., Enquist, I.F.: The water content of healing incisions. Surg Gynec Obstet 124: 7331967.

42) Hunt, T.K., et al.: Tissue oxygen tensions during controlled hemorrhage. Surg Forum 18: 31967.

43) Ehrlich, H.P., Grislis, G., Hunt, T.K.: Metabolic and circulatory contributions to oxygen gradients in wounds. Surg 72: 578 1972.

44) Hunt, T.K., Pai, M.P. : The effect of varying ambient oxygen tensions on wound metabolism and collagen synthesis. Surg Gynec Obstet 135: 5611972. 